\title{
MINAT MAHASISWA UNTUK BERWISATA KE NEGERA INDIA (Studi Kuantitatif dengan Treatment konten YouTube berjudul Rape is consensual: Inside Haryana's Rape Culture)
}

\author{
Dr. Nurhayani Saragih (nurhayani.saragih@mercubuana.ac.id) \\ Enjang Pera Irawan, M.I.Kom (enjang.irawan@ mercubuana.ac.id )
}

\begin{abstract}
Almost all countries are trying to launch tourism as a source of foreign exchange earners for their countries. Many efforts have been made to increase the number of tourists visiting. One of the tourist destinations that once entered the 7 (seven) wonders of the world is Taj-Mahal. The palace was made for 22 years by Mughal Emperor Shah Jahan for his empress. With such conditions, India is one of the tourist destinations that are worth visiting. In addition to the king's palace, India has a different culture from Indonesia.

Meanwhile, along with the development of communication technology, the number of YouTube content containing documentation about culture is increasing. YouTube viewers are also increasing in number dayly. One YouTube video of documentation of Indian culture, is entitled Rape is consensual: Inside Haryana's Rape Culture, which will be an instrument as a treatment to see if there is a difference in interest in visiting India before and after watching the YouTube video.

This study uses quantitative research methods by distributing questionnaires to 58 Mercu Buana University students who were selected purposively. That study aims to find out whether there are differences in interests between before and after watching YouTube content.

The results showed that even though there was a decrease in the mean value from 12.121 (before treatment) to 10.345 (after treatment), the calculation of the t value calculated was 5.092 while the t-table value for the two-tailed test (Two Tail) was 2.002. The t value calculated is greater than the t-table value, so it can be concluded that there is no difference in traveling interest to India before and after watching the YouTube video.
\end{abstract}

\section{Kata kunci: Vacation Intenstion, India, Rape Culture}

\begin{abstract}
ABSTRAK
Hampir semua negara berupaya untuk mencanangkan pariwisata sebagai salah satu sumber penghasil devisa bagi negaranya. Banyak upaya yang dilakukan untuk menambah jumlah wisatawan yang berkunjung. Salah satu tujuan wisata yang pernah masuk dalam 7 (tujuh) keajaiban dunia adalah Taj-mahal. Istana tersebut dibuat selama 22 tahun oleh Kaisar Mughal Shah Jahan untuk permaisurinya. Dengan kondisi seperti itu, India merupakan salah satu destinasi wisata yang layak dikunjungi. Selain istana raja tersebut, India memiliki budaya yang berbeda dengan di Indonesia.
\end{abstract}


Sementara itu, seiring dengan perkembangan teknologi komunikasi, jumlah content YouTube berisi dokumentasi tentang budaya semakin banyak jumlahnya. Penonton YouTube juga semakin hari semakin meningkat jumlahnya. Salah satu video YouTube dokumentasi budaya India, adalah yang berjudul Rape is consensual: Inside Haryana's Rape Culture yang akan menjadi instrument (perlakuan) untuk melihat apakah ada perbedaan minat untuk berkunjung ke India sebelum maupun setelah menonton video YouTube tersebut. Penelitian ini menggunakan metode penelitian kuantitatif dengan menyebarkan kuisioner pada 58 mahasiswa Universitas Mercu Buana yang dipilih secara purposive. Tujuan penelitian ini adalah ingin mengetahui adakah perbedaan minat antara sebelum dan setelah menonton content YouTube tersebut.

Hasil penelitian menunjukkan meski terjadi penurunan nilai mean dari 12,121 (sebelum treatment) menjadi 10,345 (setelah treatment), namun hasil perhitungan Nilai t Hitung adalah 5,092 sementara Nilai t-tabel untuk uji dua pihak (Two Tail) adalah 2,002. Nilai t Hitung lebih besar daripada nilai t-Tabel, maka dapat disimpulkan bahwa tidak ada perbedaan minat berwisata ke India sebelum dan setelah menonton video YouTube tersebut.

\section{Kata kunci: Minat berwisata, India, Rape Culture}

\section{PENDAHULUAN}

Presiden pada 2014 menetapkan pariwisata sebagai leading sector. Dalam program Nawa Cita target kunjungan wisatawan mancanegara (wisman) harus mencapai 20 juta pada 2019. Top 10 Branding yang siap dipasarkan Kementerian Pariwisata yaitu Bali, Jakarta, Kepri, Medan, Bandung, Joglo Semar, Surabaya, Banyuwangi, dan Makassar.

Menurut Media Indonesia (20 Oktober 2017), "Data indeks daya saing pariwisata yang penilaiannya dilakukan dua tahun sekali oleh World Economic Forum (WEF) menyebutkan, jumlah kunjungan wisman ke Indonesia terus meningkat. Di 2015, jumlahnya hanya 10 juta, tahun berikutnya naik jadi 12 juta, dan tahun ini melonjak ke 15 juta." Melihat kenaikan angka kunjungan wisatawan tersebut, Kemenpar yakin sektor pariwisata diyakini bakal menjadi pemasok devisa terbesar, melebihi devisa sektor minyak dan gas (migas). Data Kemenpar (Marketeteers.com. December 28, 2017) menunjukkan, "Secara kumulatif sejak JanuariOktober 2017 menunjukkan jumlah wisnus mencapai 252.569.465. Menteri Pariwisata Arief Yahya 
memaparkan, jumlah wisnus JanuariOktober 2017 lebih tinggi 14\% dibandingkan target yang ditetapkan sebesar 221,5 juta wisnus."

Selain wisatawan

mancanegara, saat ini masyarakat Indonesia juga senang berwisata, baik di dalam negeri, maupun ke luar negeri. Kepala Bagian Humas dan Umum Direktorat Jenderal Imigrasi, Agung Sampurno (Kompas.com 10/01/2018), "Selama tahun 2016 jumlah warga negara Indonesia yang ke luar negeri mencapai 8.4 juta orang dan melonjak di tahun 2017 mencapai 9.1 juta orang. Hal tersebut menurutnya berbanding lurus dengan lonjakan permintaan penerbitan paspor ke Ditjen Imigrasi." Direktorat Jenderal (Ditjen) Imigrasi memprediksi tahun 2018 tren wisata ke luar negeri akan semakin naik. Melonjaknya jumlah permintaan paspor dinilai berkaitan dengan alasan wisata turis Indonesia ke luar negeri. Salah satu faktor penyebabnya, kalau diasumsikan karena maraknya tiket-tiket murah, transportasi murah ke luar negeri. "Negara tujuan yang banyak dikunjungi WNI masih Asean, Asia
Pasifik, dan Australia," ungkap Kepala Bagian Humas dan Umum Direktorat Jenderal Imigrasi.

Salah satu negara yang layak dikunjungi di Asia adalah India. Nilai tambah bagi India, Perdana Menteri India Narendra Modi memutuskan turis Indonesia bebas visa untuk datang ke India. India memiliki banyak destinasi wisata unik yang bisa jadi rujukan bagi turis asing yang datang, terutama dari Indonesia (Kompas.com; 01/06/2018, 21:10 WIB). Destinasi wisata di India yang menjadi ikon antara lain: Taj Mahal merupakan istana yang dibangun oleh Kaisar Mughal Shah Jahan yang dipersembahkan untuk istrinya tercinta. Ada juga Benteng Amber, Menara Qutub, dan Ladakh yang merupakan salah satu tempat tertinggi di dunia karena berada di wilayah pegunungan Himalaya. Selain alamnya indah, budaya India juga menarik. Namun di sisi lain, berita-berita tentang India juga membuat enggan berkunjung ke India. Misalnya, Tempo.co (Selasa, 16 Januari 2018 13:15 WIB), memuat berita dengan judul 
"Perkosaan Bergilir dan Mutilasi Dua Remaja Guncang India." Perkosaan ini terjadi di Negara Bagian Haryana. Pada Januari 2018, terjadi 10 peristiwa perkosaan dalam
10 hari berturut-turut di negara bagian Haryana, yang lokasinya relatif dekat dengan Ibu Kota India, New Delhi.

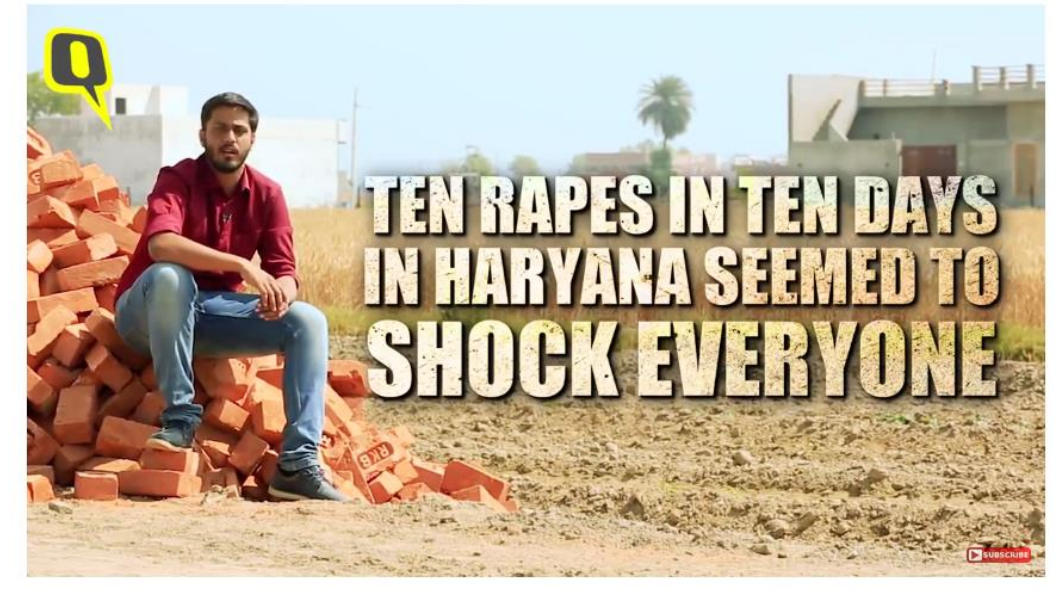

Rape is Consensual: Inside Haryana's Rape Culture I Documentary by The Quint

Sumber: Youtube, https://www.youtube.com/watch?v=Pgom8LRF8hQ\&t=7s.

Akses 26 Juli 2018 pukul 11.04 WIB.

Hal itu tergambar dalam berbagai video dokumentasi yang beredar di YouTube, salah satunya berjudul "Rape is Consensual: Inside Haryana's Rape Culture, " yang dipublikasikan pada 6 April 2018 oleh The Quint. Video YouTube tersebut menceritakan bahwa jumlah laki-laki di India relatif lebih banyak dibandingkan perempuan, dan bila terjadi perkosaan, baik perempuan maupun laki-laki, beranggapan peristiwa tersebut terjadi karena kesalahan perempuan. Perempuan dianggap sebagai penggoda. Budaya mengunggulkan laki-laki dibanding perempuan pun mendarah daging dan tertanam di benak anak laki-laki menurut video tersebut.

YouTube dipilih mengingat jumlah pengakses YouTube tiap bulannya mencapai 1.8 miliar (Kompas.Com, 4 Mei 2018). Ini jumlah penonton yang terdaftar, belum termasuk pengguna internet lain yang kerap menonton video YouTube tapi tidak memiliki akun di sana. Pada pertengahan tahun 2017, 
penonton YouTube sebesar 1.5 miliar. Pengguna tertinggi YouTube kebanyakan adalah generasi muda, yang salah satunya adalah mahasiswa.

Peneliti tertarik melakukan penelitian untuk mengetahui minat mahasiswa Universitas Mercu Buana berwisata ke India setelah menonton video tersebut, dengan rumusan masalah: "Apakah terdapat perbedaan minat mahasiswa sebelum dan setelah menonton video yuotube berjudul Rape is Consensual: Inside Haryana's Rape Culture?

\section{TINJAUAN PUSTAKA}

Penelitian terdahulu baik berupa tesis, ataupun juga jurnal yang terbit dalam skala nasional maupun internasional tentunya memiliki berbagai macam pandangan yang berbeda mengenai objek kajian. Peneliti belum menemukan penelitian menggunakan kuantitatif mengenai minat berwisata ke India, apalagi membandingkan antara sebelum dan setelah menonton video YouTube.

Penelitian terdahulu yang membahas tentang YouTube dan
India adalah penelitian Yessi Mareta berjudul Representasi Perdamaian Pada Iklan Coca-Cola Edisi: CocaCola Small Word Machines-Bringing India And Pakistan Together Di Media YouTube. Penelitian ini menggunakan metode kualitatif dengan analisis semiotika Roland Barthes untuk mengetahui tanda atau simbol apa yang digunakan untuk mempresentasikan perdamaian dalam iklan Coca-Cola edisi Coca-Cola Small Word Machines Bringing India and Pakistan Together yang dipublikasikan di media YouTube pada 19 Mei 2013.

$$
\text { Penelitian }
$$

berikutnya dilakukan oleh Oloan Siregar dan Mario Antonius Birowo berjudul Tanggapan Traveler Wanita Indonesia terhadap Pemberitaan Kasus Pemerkosaan di India. Penelitian Siregar dan Birowo menggunakan analisis deskriptif kualitatif dengan mewawancara lima traveler wanita Indonesia dari grup "Backpacker Dunia" sebagai subyek penelitian dalam melihat pemberitaan kasus-kasus pemerkosaan yang marak terjadi di India. 
Di Indonesia, sejak hanya ada stasiun TVRI saja hingga sekarang ada saja stasiun televisi yang menayangkan film India, khususnya di ANTV dan Indosiar. Bahkan ada satu masa ketika film Mahabarata ditayangkan, artis-artis dari India menjadi bintang tamu di acara televisi Indonesia. Artis-artis tersebut didatangkan dengan maksud memenuhi animo masyarakat yang ingin tahu tentang pemain film tersebut, juga untuk menambah jumlah penonton. Televisi adalah komunikator massa yang memilih pesan sesuai tujuannya, yaitu memberi informasi, mendidik, dan menghibur massa-nya. Pesan-pesan komunikasi kini lebih banyak didistribusikan menggunakan media komputer dengan teknologi digital, yang disebut dengan ComputerMediated-Communication (CMC).

Computer-MediatedCommunication (CMC) can be any form of communication that is mediated by digital tecnology. Thus, a telephone conversation can be said to be computer mediated if each speech act is converted into digital code, transmitted, and then decoded for the listener (Littlejohn and Foss, 2009: 161-162).
Komunikasi yang dimediasi perangkat komputer terjadi dalam berbagai tipe, mulai pada tataran komunikasi personal, organisasi, atau komunikasi massa. Bahkan saat ini komunikasi menggunakan media didominasi oleh perangkat komunikasi dengan teknologi digital (internet) yang memungkinkan tiap individu menjadi komunikator melalui akun media sosial yang dipublish, kemudian dibaca banyak orang secara serentak dalam satu waktu, meskipun mereka terpisah jarak.

Saat ini setiap orang membutuhkan akses terhadap internet dan media sosial. Kebutuhan akan informasi, hiburan, pendidikan, dan akses pengetahuan dari belahan bumi yang berbeda semakin tinggi. "The world is flat," demikian ungkap Thomas L. Friedman (2007). Bahwa dunia semakin datar, tiap orang dapat mengakses berbagai informasi dari berbagai sumber. Kehadiran media baru (new media/cyber media) menjadikan informasi sebagai sesuatu yang 
mudah dicari dan terbuka (Richard Hunter dalam Nasrullah, 2015).

Sementara Van Dijk (2013) mendefinisikan media sosial sebagai platform media yang yang memfasilitasi pengguna dalam beraktivitas dan berkolaborasi. Media sosial dapat dilihat sebagai medium (fasilitator) online yang menguatkan hubungan antara pengguna sekaligus sebagai sebuah ikatan sosial.

Media sosial memiliki karakteristik yang tidak dimiliki media lainnya. Media sosial beranjak dari pemahaman bagaimana dunia virtual menggunakan media sebagai sarana sosial. Karakteristik media sosial, antara lain: Jaringan (Network), antarpengguna; Informasi (Information); Arsip (Archieve); Interaksi (Interactivity); dan Simulasi (Simulation Sosial). YouTube adalah salah satu media yang memenuhi karakteristik tersebut.

Menurut Nasrullah (2015), "YouTube adalah situs media sosial yang memungkinkan anggota untuk menyimpan dan berbagi gambar, postcast, dan video secara online. YouTube adalah situs berbagi media (media sharing). YouTube memfasilitasi penggunanya untuk berbagi isi pesan, seperti dokumen, video, audio, maupun gambar. Kebanyakan dari media sosial ini tidak berbayar, meskipun ada yang mengenakan biaya keanggotaan berdasarkan fitur yang digunakan. Fungsi media tradisional kini bisa diperoleh dari internet. YouTube memberikan pilihan alternatif tayangan audio-visual bagi program komunikasi massa berbasis audio visual.

Video YouTube dalam penelitian ini adalah salah satu contoh konten yang dapat diakses kapan saja dan dimana saja (tergantung pengguna). Hal ini menyebabkan kehadiran internet dan media-media di dalamnya, menjadi lebih mendominasi dibandingkan penggunaan media main stream, khususnya di kalangan generasi muda.

Konten media dibuat tentu dengan tujuan tertentu, sesuai dengan motif komunikator ketika merancang pesan komunikasi. Menurut Rogers (dalam Mulyana, 2007: 69), "Komunikasi adalah proses dimana 
suatu ide dialihkan dari sumber kepada penerima dengan maksud untuk mengubah tingkah laku mereka." Komunikator membuat pesan untuk menarik perhatian penonton sebanyak mungkin, kemudian penonton akan terpengaruh secara kognitif, afektif hingga mampu mengubah tingkah laku komunikan. Minat adalah efek dari komunikasi yang membangkitkan keinginan untuk bertindak sesuai arahan komunikator (sesuai isi pesan). Isi pesan video YouTube tentang India dipilih sebab, meski beredar banyak informasi tentang tindak kekerasan terhadap perempuan di India, belum tentu semua khalayak membaca dan menyadari peristiwa terkait tindak kekerasan dan pemerkosaan terhadap perempuan yang terjadi di India.

\section{MINAT BERWISATA KE INDIA}

Minat adalah hal yang
mendorong seseorang untuk
melakukan suatu tindakan, yang
dalam konteks penelitian ini
mendorong orang untuk berwisata.
Sementara wisata atau tourism
menurut Sugiyono, Parmariza dan

Ali (2018) adalah, "Something related to tourism including exploitation, attraction and tourist attraction as well as efforts related to the implementation of tourism.... Tourists are consumers or users of products and services." Banyak hal yang menyebabkan orang ingin berkunjung ke suatu tempat atau negara yang berbeda dari asalnya. Minat berwisata itu bisa tumbuh karena aspek:

1) Cultural aspects. In the cultural aspect, tourists will focus attention on dance, music, art, kerajianan, patterns of community tradition, specific economic activities, archeology and history.

2) Natural Aspect. In the natural aspect, tourists can focus on the flora, fauna, geology, national parks, forests, rivers, lakes, beaches, marine and certain ecosystem behaviors.

Umumnya yang membuat orang berminat melakukan perjalanan wisata karena aspek budaya dan aspek alami dari daerah pariwisata yang ingin dikunjungi. India adalah salah satu negara yang secara budaya (tradisi, tarian, kostum spesifik yang berbeda dengan budaya lain), dan memiliki istana Taj Mahal yang 
semula dikenal sebagai salah satu dari tujuh keajaiban dunia. Perjalanan wisata terjadi bukan saja karena adanya minat, tetapi juga harus didukung karena adanya faktor finansial dan alokasi waktu dari orang yang berminat melakukan perjalanan wisata. Selain itu, dalam konteks penelitian ini, karena banyak pemberitaan negatif terkait pemerkosaan dan tindak kekerasan terhadap perempuan, hal itu adalah salah satu aspek penting yang perlu menjadi pertimbangan dalam perencanaan dan realisasi perjalanan wisata. Suatu negara dianggap sebagai destinasi wisata yang menarik karena pemberitaan media tentang berbagai hal, termasuk tentang tindak kriminal, yang menjadi sebab suatu negara dianggap tidak menarik bagi para traveler. Negara India sempat menjadi sorotan karena pemberitaan tentang kasus pemerkosaan di negara tersebut, yang menimpa warga lokal dan asing.

\section{METODE PENELITIAN}

Penelitian ini termasuk dalam penelitian kuantitatif menekankan analisisnya pada data numerik (angka) yang diolah dengan metode Statistika. Metode pendekatan dalam penelitian ini adalah eksperimental. Menurut Prasetyo (2005: 156-157), "Penelitian ... yang mengukur hubungan sebab-akibat. Penelitian pada ilmu-ilmu sosial dapat menciptakan laboratorium dengan lingkungan alami sehingga tidak terasa diteliti. Penelitian ini disebut penelitian eksperimen lapangan/ field eksperiment."

Penelitian eksperimen lapangan merupakan kajian penelitian dalam situasi nyata (realitas), dengan memanipulasi suatu variabel bebas dalam kondisi yang dikontrol oleh pembuat eksperimen sejauh situasinya memungkinkan. Prosedur penelitian bermaksud membandingkan efek variasi variabel bebas terhadap variabel tergantung melalui manipulasi atau pengendalian variasi bebas tersebut. Perubahan yang terjadi pada variabel tergantung akan dikendalikan penyebabnya pada perbedaan perlakuan yang diberikan pada variabel bebas. Dalam 
penelitian ini, yang menjadi treatment (manipulasi) untuk melihat apakah ada perubahan pada variabel minat berwisata ke India setelah menonton video YouTube berjudul Rape is consensual: Inside Haryana's Rape Culture.

Populasi adalah wilayah generalisasi yang terdiri atas objek atau subyek yang mempunyai kualitas dan karakteristik tertentu yang ditetapkan oleh peneliti untuk dipelajari kemudian ditarik kesimpulan. (Sugiyono, 2009: 117). Populasi penelitian ini adalah mahasiswa Mercu Buana yang sedang mengambil mata kuliah Riset Komunikasi di kelas reguler 1 dan reguler 2 untuk melihat variasi nilai jawaban responden karena adanya variasi identitas. Pada kelas reguler 1 mahasiswa lebih muda (langsung kuliah begitu selesai SMA) dan belum bekerja, serta usianya lebih muda. Sementara mahasiswa reguler 2 adalah mahasiswa yang sudah bekerja dan usianya lebih tua dibandingkan mahasiswa reguler 1 .

Teknik pengambilan sampel menggunakan nonprobability sampling jenis purposive.
Nonprobabilty sampling adalah teknik pengambilan sampel yang tidak memberikan kesempatan yang sama bagi setiap unsur atau anggota populasi untuk dipilih menjadi sampel. Sampel purposive adalah teknik menentuan sampel dengan pertimbangan tertentu (Sugiyono, 2009: 124). Sampel bertujuan dilakukan dengan cara mengambil subjek bukan berdasarkan atas strata, random atau daerah tetapi berdasarkan atas adanya tujuan tertentu. Teknik ini dilakukan karena pertimbangan alasan keterbatasan waktu, tenaga dan dana, sehingga tidak dapat mengambil sampel yang besar atau jauh. Peneliti menggunakan purposive sample karena peneliti dapat memilih sumber data sesuai dengan variabel yang diteliti. Pengumpulan data bila dilihat dari setting-nya, dikumpulkan pada setting alamiah (natural setting).

Sampel dalam penelitian adalah seluruh mahasiswa Reguler 1 yang mengambil mata kuliah Riset Komunikasi (Kamis pukul 07.30 10.00 WIB) yang jumlahnya 40 orang; dan mahasiswa Reguler 2 
yang mengambil mata kuliah Peduli Negeri (Sabtu pukul $07.30-10.00$ WIB) yang jumlahnya 35 orang. Mengingat kuisioner sebelum treatment didistribusikan di awal kuliah, yang menjadi sampel adalah mahasiswa yang datang tepat waktu, serta mengisi kuisioner sebelum dan setelah menonton video secara lengkap.

Validitas dalam penelitian eksperimen terdiri dari dua macam yaitu: validitas yang berhubungan dengan efek yang ditimbulkan atau biasa yang disebut dengan validitas internal dan validitas yang berhubungan dengan penerapan hasil eksperimen atau biasa disebut validitas eksternal.

Validitas internal berkaitan dengan sejauhmana hubungan sebab akibat antara variabel bebas dan variabel terikat yang ditemukan dalam penelitian. Semakin kuat hubungan sebab akibat antara variabel bebas dan variabel terikat maka semakin besar validitas internal suatu penelitian.

Pada penelitian ini, untuk meningkatkan validitas internal berlaku ketentuan: hanya responden yang mengisi kuisioner pre-test dan post-test secara lengkap yang hasilnya akan dihitung dalam penelitian ini. Sedangkan mahasiswa yang terlambat hadir, meski mengisi kuisioner post-test saja, tidak akan dihitung. Jumlah masing-masing kelas reguler 1 dan reguler 2 setelah diperiksa, ada 29 responden yang memenuhi syarat tersebut. Dengan demikian, responden penelitian ini berjumlah 58 orang.

$$
\text { Menurut Kriyantono }
$$
(2007:140), "Suatu alat ukur disebut realibel bila alat ukur tersebut secara konsisten memberikan hasil atau hasil terhadap gejala yang sama, walau digunakan berulang kali. Reliabilitas mengandung arti bahwa alat ukur tersebut stabil (tidak berubah-ubah), dapat diandalkan (dependable), dan tetap/ajeg (consitent)."

Untuk menghitung reliabilitas instrumen peneliti menggunakan perhitungan dengan SPPS, hasilnya harga $r$ hitung dikonsultasikan dengan $r$ dengan $=5 \%$. Jika $>$ r-tabel, maka instrumen dikatakan reliabel dan jika < r-tabel maka instrumen dikatakan tidak reliabel. Hasil uji 
reliabilitas dengan $\mathrm{r}=5 \%$ adalah 0,254 sementara hasil hitung 0,902 . Dengan demikian $r$ hitung > r-tabel, sehingga instrument penelitian dapat dikatakan valid dan reliabel.

Analisa data penelitian

dilaksanakan dengan cara:

a) Analisis Data Tahap Awal, dilakukan sebelum penelitian. Analisis ini bertujuan untuk memilih kuisioner pre-test dan kuisioner post-test yang diisi secara lengkap oleh responden.

b) Setelah diperoleh jumlah kuisioner yang layak dihitung, untuk mengetahui jawaban tiap pertanyaan, digunakan tabel distribusi frekuensi;

c) Sementara untuk mengetahui apakah ada kesamaan (perbedaan) rata-rata variabel minat berwisata sebelum menonton dan minat berwisata ke India setelah menonton video YouTube tersebut, digunakan program Excel untuk uji T.

\section{HASIL PENELITIAN DAN PEMBAHASAN}

Hasil penelitian diperoleh dengan menyebarkan kuisioner pada mahasiswa. Kuisioner terdiri dari 5 (lima) pernyataan dengan 4 (empat) pilihan jawaban: Sangat Tidak Setuju (STS dengan point 1); Tidak Setuju (TS dengan point 2); Setuju (S dengan point 3), dan Sangat Setuju (SS dengan point 4).

Responden penelitian seluruhnya berjumlah 58 orang, terdiri dari sebagian besar $(83 \%)$ berjenis kelamin perempuan, sementara laki-laki hanya $10(17 \%)$. Umur sebagian besar (34 atau $58,6 \%$ ) responden berusia 21-24 tahun, 11 orang (19\%) berumur kurang dari 20 tahun, diikuti usia 2529 tahun sebanyak 10 orang $(17,2 \%)$, sisanya sebanyak 3 mahasiswa berusia antara $30-44$ tahun. Sebagian besar 49 orang $(84,5 \%)$ masih single. Dari 58 responden, sebagian besar (45 responden atau $77,6 \%$ ) belum pernah berwisata ke luar negeri dalam lima tahun terakhir.

\section{Tabel-tabel}

berikut menunjukkan hasil penelitian sebelum dan setelah responden menonton video YouTube:

Tabel 1: India adalah Negara yang Indah

\begin{tabular}{|l|l|l|}
\hline & Sebelum & Setelah \\
\hline
\end{tabular}




\begin{tabular}{|l|r|r|r|c|}
\hline & Frekuensi & \multicolumn{1}{|c|}{$\%$} & Frekuensi & $\%$ \\
\hline $\begin{array}{l}\text { Sangat Tidak } \\
\text { Setuju }\end{array}$ & 5 & 8,6 & 13 & 22,4 \\
\hline Tidak Setuju & 18 & 31,0 & 21 & 36,2 \\
\hline Setuju & 32 & 55,2 & 22 & 37,9 \\
\hline Sangat Setuju & 3 & 5,2 & 2 & 3,4 \\
\hline Total & 58 & 100 & 58 & 100 \\
\hline
\end{tabular}

Untuk pernyataan 1, sebelum menonton video YouTube sebagian besar $(55,2 \%)$ responden setuju pernyataan bahwa India adalah negara yang indah, sementara setelah menonton 10 responden mengganti jawaban menjadi tidak setuju, dan sangat tidak setuju. Ada perubahan pendapat dari positif menjadi negatif. Sementara yang menjawab Sangat Setuju berkurang dari 3 sebelum menonton, menjadi 2 responden.

Tabel 2: Budaya Masyarakatnya Membuat Saya Ingin Berkunjung Ke India

\begin{tabular}{|l|r|r|r|r|}
\hline & \multicolumn{2}{|c|}{ Sebelum } & \multicolumn{2}{c|}{ Setelah } \\
\cline { 2 - 5 } & Frekuensi & \multicolumn{1}{c|}{$\%$} & Frekuensi & $\%$ \\
\hline $\begin{array}{l}\text { Sangat Tidak } \\
\text { Setuju }\end{array}$ & 9 & 15,5 & 14 & 24,1 \\
\hline Tidak Setuju & 20 & 34,5 & 30 & 51,7 \\
\hline Setuju & 25 & 43,1 & 11 & 19,0 \\
\hline Sangat Setuju & 4 & 6,9 & 3 & 5,2 \\
\hline Total & 58 & 100 & 58 & 100 \\
\hline
\end{tabular}

Tabel di atas menunjukkan sebelum treatment, $25 \quad(43 \%)$ responden memilih setuju, namun setelah menonton 14 responden berubah jawab menjadi tidak setuju dan sangat tidak setuju. Ada perbedaan jawaban yang tetap ingin berkunjung berubah dari separuh (29 atau $50 \%)$ menjadi hanya $14(24 \%)$ responden saja.

Tabel 3:

Jika Mempunyai Uang, Saya Akan Berwisata Ke India

\begin{tabular}{|l|r|c|r|c|}
\hline \multirow{2}{*}{} & \multicolumn{2}{|c|}{ Sebelum } & \multicolumn{2}{c|}{ Setelah } \\
\cline { 2 - 5 } & Frekuensi & $\%$ & Frekuensi & $\%$ \\
\hline Sangat Tidak & 6 & 10,3 & 11 & 19,0 \\
\hline
\end{tabular}




\begin{tabular}{|l|r|r|r|r|}
\hline Setuju & & & & \\
\hline Tidak Setuju & 23 & 39,7 & 29 & 50,0 \\
\hline Setuju & 25 & 43,1 & 15 & 25,9 \\
\hline Sangat Setuju & 4 & 6,9 & 3 & 5,2 \\
\hline Total & 58 & 100 & 58 & 100 \\
\hline
\end{tabular}

Tabel di atas hampir mirip dengan tabel-tabel sebelumnya. Ada perubahan sebagian $29 \quad(50 \%)$ responden menjawab Setuju dan sangat setuju berkurang menjadi 18 (31\%) saja yang akan memilih India sebagai tujuan wisata bila mereka memiliki uang.

Tabel 4:

Jika Mempunyai Waktu, Saya Akan Berwisata Ke India

\begin{tabular}{|l|r|r|r|r|}
\hline & \multicolumn{2}{|c|}{ Sebelum } & \multicolumn{2}{c|}{ Setelah } \\
\cline { 2 - 5 } & Frekuensi & $\%$ & Frekuensi & $\%$ \\
\hline $\begin{array}{l}\text { Sangat Tidak } \\
\text { Setuju }\end{array}$ & 5 & 8,6 & 9 & 15,5 \\
\hline Tidak Setuju & 23 & 39,7 & 27 & 46,6 \\
\hline Setuju & 27 & 46,6 & 20 & 34,5 \\
\hline Sangat Setuju & 3 & 5,2 & 2 & 3,4 \\
\hline Total & 58 & 100 & 58 & 100 \\
\hline
\end{tabular}

Pada pernyataan 4 , pola yang sama seperti pernyataan 1,2 , dan 3 . Dari 52\% (30) responden akan berwisata ke India, menurun menjadi

Tabel 5:

Saya Akan Mengajak Saudara Perempuan Berwisata Ke India

\begin{tabular}{|l|r|r|r|r|}
\hline & \multicolumn{2}{|c|}{ Sebelum } & \multicolumn{2}{c|}{ Setelah } \\
\cline { 2 - 5 } & Frekuensi & $\%$ & Frekuensi & $\%$ \\
\hline $\begin{array}{l}\text { Sangat Tidak } \\
\text { Setuju }\end{array}$ & 11 & 19,0 & 20 & 34,5 \\
\hline Tidak Setuju & 17 & 29,3 & 30 & 51,7 \\
\hline Setuju & 28 & 48,3 & 8 & 13,8 \\
\hline Sangat Setuju & 2 & 3,4 & 0 & 0 \\
\hline Total & 58 & 100 & 58 & 100 \\
\hline
\end{tabular}


Tabel di atas menunjukkan penurunan jumlah sebesar 22 (38\%). Semula separuh (30 atau 51,7\%) mengajak saudara perempuannya, turun menjadi hanya $8(13,8 \%)$ saja yang akan mengajak saudara perempuannya berwisata ke India. Sementara hasil uji beda menunjukkan ada penurunan nilai mean sebesar 1, 775 dari 12,121 menjadi 10,345. Nilai t Hitung adalah 5,092 sementara Nilai t-tabel untuk uji dua pihak (Two Tail) adalah 2,002. Karena nilai t Hitung lebih besar daripada nilai t-Tabel, maka dapat disimpulkan bahwa ratarata minat responden sebelum dan setelah menonton adalah sama, atau tidak ada perbedaan minat berwisata baik sebelum maupun setelah menonton video YouTube.

Hasil perhitungan pada pernyataan 1 sampai dengan 5 menunjukkan ada perubahan minat responden sebelum dan setelah treatment. Angkanya relatif hampir mirip pada tiap pernyataan, namun perubahan angka terbesar adalah pada pernyataan 5 (mengajak saudara perempuan ke India). Tampaknya para responden tidak mau mengambil risiko terjadinya hal yang tidak diinginkan (tindak kekerasan, perkosaan, pelecehan seksual) atas keluarga. Berkunjung ke India mengajak saudara perempuan tidak sebanding dengan risiko yang kemungkinan akan terjadi. Usianya tampaknya berpengaruh terhadap minat responden berwisata sebelum dan setelah menonton video YouTube. Responden yang relatif muda cenderung berubah (dari berminat menjadi tidak berminat), sementara responden yang lebih tua minatnya cenderung tetap (tidak ada perbedaan). Selain faktor usia, satu responden yang tetap mengajak saudara perempuan ke India adalah responden yang bekerja di perusahaan milik warga negara India, jadi sudah terbiasa dengan karakteristik orang India.

Meski perhitungan per pernyataan menunjukkan ada perbedaan, namun secara menyeluruh hasil perhitungan menunjukkan sebelum dan setelah treatment, minat responden relatif sama (tidak ada perbedaan). Hasil ini menunjukkan bahwa video YouTube tersebut tidak mengakibatkan 
responden menjadi enggan berwisata ke India. Sebelum dan setelah menonton video YouTube, minat responden berwisata ke India bila dilihat dari mean sebelum dan setelah treatment relatif pada tingkat sedang.

Apakah konten video YouTube sama sekali tidak punya pengaruh? Data awal menunjukan bahwa saat ini menonton video YouTube adalah salah satu aktivitas tertinggi yang menyebabkan jumlah penonton media main stream (televisi) berkurang. Meski jumlah waktu menonton YouTube bertambah, namun hasil penelitian ini menunjukkan bahwa konten YouTube tidak berpengaruh terhadap responden. Banyaknya konten YouTube yang makin hari jumlahnya bertambah menyebabkan berbagai informasi mudah diperoleh. Pada saat yang sama, karakter pengkonsumsi YouTube selalu mencari konten yang sesuai dengan minat masing-masing individu. Konten YouTube berguna untuk menambah pengetahuan responden mengenai kondisi masyarakat di suatu negara, tapi tidak berpengaruh signifikan terhadap minat berkunjung.

Hasil ini sejalan dengan hasil penelitian Siregar dan Birowo yang menyimpulkan bahwa para traveler wanita Indonesia menganggap berita pemerkosaan di India sebenarnya tidak berbeda dengan berita pemerkosaan yang terjadi di negara lain. Mereka tetap menganggap berita ini penting untuk meningkatkan awareness tentang risiko dan menjaga keamanan saat traveling. Efek behavioral timbul dalam diri mereka setelah membaca berita kasus-kasus pemerkosaan di India agar tidak menjadi korban atas kejadian kriminal tersebut. Meskipun demikian, mereka tetap menganggap bahwa pemerkosaan bukanlah hal yang paling menakutkan yang bisa menimpa mereka saat traveling. Pemberitaan kasus pemerkosaan yang marak terjadi di India juga tidak mengubah ketertarikan para traveler wanita Indonesia terhadap negara India sebagai destinasi traveling.

Di sisi lain, penelitian ini mengungkap bahwa India bukanlah target wisata bagi responden penelitian ini, apalagi bila bersama 
dengan kerabat perempuan. Dari hasil wawancara dengan beberapa responden, Eropa masih menjadi magnet utama untuk berwisata, diikuti dengan keinginan untuk menjelajah berbagai daerah wisata di Indonesia. Untuk responden penelitian ini, melakukan perjalanan wisata juga belum menjadi prioritas sebab sebagian besar $(77,6 \%)$ responden dalam lima tahun terakhir belum pernah berwisata ke luar negeri. Hal ini terkait dengan usia $58 \%$ responden kurang dari 20 sampai 24 tahun, bagi mereka menggunakan waktu untuk menyelesaikan kuliah masih menjadi prioritas.

\section{KESIMPULAN}

Kelompok muda cenderung menghabiskan banyak waktu untuk mengkonsumsi media digital, namun tampaknya konten YouTube tidak memiliki dampak significant dalam penelitian ini. Di sisi lain, banyaknya konten YouTube, dan menghabiskan banyak waktu menonton YouTube juga tidak berpengaruh terhadap minat salah satu penyebabnya adalah karena menonton sambil melakukan pekerjaan lainnya, sehingga tidak fokus dengan informasi yang disampaikan dalam konten.

Banyak kendala dalam melakukan penelitian eksperimen dalam latar situasi kelas yang tanpa rekayasa. Mengingat kuisioner sebelum treatment didistribusikan tepat diawal waktu kuliah, sebagian kuisioner setelah menonton terpaksa tidak digunakan karena tidak mengisi kuisioner sebelum menonton. Kendala lainnya, video YouTube ini menggunakan bahasa Inggris. Ternyata di era teknologi digital penguasaan bahasa Inggris menjadi kendala untuk memahami informasi konten YouTube.

Berdasarkan hasil penelitian ini, tampaknya minat generasi muda Indonesia berwisata ke negara lain masih dalam kategori sedang. Berdasarkan data ini, pemerintah dapat menyasar target audiens dalam kategori ini untuk menghabiskan dana dan waktu mereka tidak berwisata ke luar negeri, tapi justru pemerintah wajib membuat 
kampanye wisata yang membuat kelompok ini untuk mengutamakan wisata dalam negeri. Bila geliat wisata dalam negeri meningkat, tentu akan meningkatkan kesejahteraan Indonesia secara menyeluruh.

\section{UCAPAN TERIMA}

Penulis mengucapkan terima kasih pada Pimpinan Universitas Budi Luhur yang telah memuat tulisan ini dan Universitas Mercu Buana yang telah memfasilitasi penelitian ini dilakukan.

\section{DAFTAR PUSTAKA}

\section{Buku:}

Littlejohn, Stephen Stephen W., and Foss, Karen A., (Ed). 2009. Encyclopedia Communication Theory. USA: SAGE Publications Ltd.

Mulyana, Deddy. 2007. Ilmu Komunikasi, Suatu Pengantar. Bandung. Remaja Rosdakarya.

Nasrullah, Rulli. 2015. Media Sosial. Perspektif Komunikasi, Budaya dan Sosioteknologi. Bandung: Simbiosa Rekatama Media.
Kriyantono, Rachmat. 2007. Riset Komunikasi, disertai contoh praktis riset Media, PR, Advertising, Komunikasi Organisasi, Komunikasi Pemasaran. Kencana. Jakarta.

Sugiyono. 2009. Metodologi Penelitian Pendidikan, Bandung: CV Alfabeta.

\section{Journal:}

Sugiyono, Parmariza. Yennida dan Ali, Hapzi. 2018. Analysis of Optimization of the Number of Foreign in Indonesia dalam Scholars Journal of Economics, Business and Management (SJEBM) e-ISSN 2348-5302. SAS Publishers (Scholars Academic and Scientific Publishers), A Unit of Scholars Academic and Scientific Society, India. 
Yessi Mareta Andari Putri, Universitas Mercu Buana Jakarta, Representasi Perdamaian Pada Iklan Coca-Cola Edisi : Coca-Cola Small Word Machines-Bringing India And Pakistan Together Di Media Youtube.

publikasi.mercubuana.ac.id/index.ph p/mediakom/articlel.../1708. Akses 28 Agustus 2018 pukul 12.21 WIB

Oloan Siregar dan Mario Antonius Birowo berjudul Tanggapan Traveler Wanita Indonesia Terhadap Pemberitaan Kasus Pemerkosaan Di India (Analisis Deskriptif Kualitatif Tentang Tanggapan Traveler Wanita Indonesia Di Komunitas Online "Backpacker Dunia" Terhadap Pemberitaan Kasus-Kasus Pemerkosaan Yang Terjadi Di India), Program Studi Ilmu Komunikasi Fakultas Ilmu Sosial Dan Ilmu Politik, Universitas Atma Jaya Yogyakarta. $e$ journal.uajy.ac.id/6483/1/KOM 002240.pd. Akses 28 Agustus 2018 pukul 12.21 WIB

Kompas.com - 10/01/2018, 09:00 WIB. "Tahun 2018, Semakin Banyak Turis Indonesia Liburan ke Luar Negeri", https://travel.kompas.com/read/ 2018/01/10/090000527/ tahun2018-semakin-banyak-turisindonesia-liburan-ke-luarnegeri. Akses 26 Juli 2018, pukul 09.23 WIB.

Kompas.com - 01/06/2018, 21:10 WIB. Turis Indonesia Bebas Visa, Ini 5 Pilihan Obyek Wisata di India ", https://travel.kompas.com/read/ 2018/06/01/211000027/turisindonesia-bebas-visa-ini-5pilihan-obyek-wisata-di-india-. Akses 26 Juli 2018, pukul 09.27 WIB.

Kompas.com - 01/05/2018, 14: 25 WIB. Berapa Banyak Orang yang Menonton YouTube Setiap Harinya?, https://google.co.id/amp.kompa s.com/tekno/read/2018/05/1425 0087/berapa-banyak-orangyang-menonton-youtubesetiap-harinya-. Akses 11 Oktober 2018, pukul 10.27 WIB.

Website:
Marketeteers.com. December 28, 2017. Melihat Tren Wisatawan Nusantara Tahun 2017. http://marketeers.com/melihattren-wisatawan-nusantaratahun-2017/. Akses 25 Juli 2018, pukul 08.29 WIB. 
Media Indonesia. Jumat, 20 Okt 2017, 15:40 WIB. Menjadikan Pariwisata DNA Perekonomian. http://mediaindonesia.com/read /detail/128189- menjadikanpariwisata-dna-perekonomian. Akses 25 Juli 2018 pukul 07.54 WIB.

Youtube,

https://www.youtube.com/watc $\mathrm{h}$ ? $\mathrm{v}=$ Pgom8LRF8hQ\& $\mathrm{t}=7 \mathrm{~s}$. Akses 26 Juli 2018 pukul 11.04 WIB.
Wikipedia.org.

https://id.wikipedia.org/wiki/H aryana. Akses 26 Juli 2018 pukul 11.13 WIB.

Tempo.co. Selasa, 16 Januari 2018 13:15 WIB. Perkosaan Bergilir dan Mutilasi Dua Remaja Guncang India. https://dunia.tempo.co/read/10 50852/perkosaan-bergilir-danmutilasi-dua-remaja-guncangindia. Akses, 26 Juli 2018 pukul 11.27 WIB. 